\title{
"Re-Imagining" the Homeland? Languages and National Belonging in Ukrainian Diasporas since the Euromaidan
}

\author{
Ivan Kozachenko \\ University of Cambridge
}

\begin{abstract}
From the first days of the Euromaidan protests, Ukrainian diasporas around the globe took an active part in supporting democratic change in Ukraine. These diasporic communities actively used social media to "represent" their national identity, to promote their visions of Ukraine's past and future, and to network and coordinate their actions. This paper argues that the events of the Euromaidan made Ukrainian diasporas in Western countries "re-invent" and "re-imagine" their national belonging. In these processes historical memory, language, and regional identifications play a crucial part within the continuum between conservative ethnonationalist identities and "civic" ones that try to accommodate the ethnic and linguistic diversity of Ukraine in the diasporic setting. This study reveals that "civic" identity elements became more visible across Ukrainian diasporas, but that Russian aggression somewhat haltered the acceptance of diversity and reinforced previously existing conservative sentiments. ${ }^{1}$
\end{abstract}

Keywords: digital diaspora, Ukraine, "civic" and "ethnic" nationalism, social media, language, Euromaidan.

\section{INTRODUCTION}

$\mathrm{H}_{\mathrm{t}}$

istorically, Ukrainian diaspora communities have played a crucial role in the life of the homeland. They actively participated in the development of political institutions after Ukraine's independence in 1991 and then were deeply involved in a democratic transition of the country of origin. At the same time, social and political changes in the homeland have affected the diasporic national "imagination," changing and altering the sense of belonging (Anderson 6). As previously pointed out by Ewa Morawska, diasporic relationships with the homeland are neither "frozen in time" and

\footnotetext{
1 This research was completed with the support of the AHRC "Multilingualism: Empowering Individuals, Transforming Societies" project, University of Cambridge, and the Stasiuk Family Endowment Fund, CIUS, University of Alberta. I am indebted to three anonymous reviewers for their insightful comments. Also, I would like to thank Volodymyr Kulyk and Guzel Yusupova for their helpful suggestions concerning an earlier version of this paper.
} 
idealized, nor are they detached from the actual diasporic context "on the ground" (1030). Instead, these relationships and the diasporic national "imagination" are dynamic, often contradictory, and diverse. Dramatic events in the homeland may thereby cause significant changes in the national "imagination" and articulations of the sense of belonging. Such events have been taking place in Ukraine since 2013. There is little doubt that the Euromaidan revolution and Russian aggression have a fundamental influence on the whole Ukrainian national project. A number of studies (Kulyk; Kuzio; Marples and Mills) focus on an analysis of the ongoing changes in Ukrainian national ideas and identity. Here, discussions on statuses and future of Ukrainian and Russian languages play a crucial role. A number of authors have come to the conclusion that Ukrainian national identity became more "civic" and inclusive after the Euromaidan. For instance, a study by Volodymyr Kulyk ("Identity in Transformation") illustrates that the sense of belonging to Ukraine after 2014 has become more salient and has predominantly "civic" elements; it has also been widely internalized by the Russian-speakers. There are, however, less optimistic views of post-Euromaidan developments in Ukraine. For instance, Ivan Katchanovski argues that the revolution allowed oligarchic and far-right groups to consolidate their control over Ukraine, and the country became less democratic than under Ianukovych ("The 'Euromaidan"'). Considering these ideas and the far-reaching effects of recent events in Ukraine, it is important to address the questions of national belonging within Ukrainian diasporic communities and ask whether they also became more "civic" and inclusive after the Euromaidan, or not.

Diasporic nationalism in this study is scrutinized through symbolic representations of the homeland by Ukrainian diasporas in five countries. Here, "representation" reflects two crucial aspects. First, it corresponds to the ideas of Pierre Bourdieu on the work of representation that social actors (diasporas and diasporic subjects in this paper) constantly perform in order to promote their view of the world and their positions in this world (727). Bourdieu also points out that particular individuals or "spokesmen" have the power to "speak and act in the name of the group" or represent it (740). In this paper diaspora leaders and activists are seen as such "spokespersons." Second, as pointed out by Angel Parham, diasporic online "representation" refers to the showcase of the nation and/or culture of the diaspora by the use of certain symbols, narratives, and behaviours on the Internet (353). Considering these theorizations, the analysis of representations of national identity in different host countries provides insights into the ways dramatic events change the relationships between diaspora groups and their homeland in terms of national "imagination" and its representation. Using ideas on diaspora contributed by Morawska, Daniel Naujoks, and Maria Koinova, this paper traces "civic" and "ethnic" elements of such 
representation by Ukrainian diasporas after 2014 as related to memory, languages, ethnicity, and regionalism.

To address these issues, this study employs several qualitative research techniques: qualitative content analysis of social media groups, link analysis, and expert interviews with diaspora activists. The study reveals a greater acceptance and awareness of Ukraine's cultural and linguistic diversity within diasporic communities. The analysis of on- and offline representations, however, uncover a divide between communities that focus on conservative national narrative, ethnic culture, and promotion of Ukrainian monolingualism, and communities that try to accommodate and represent the linguistic, ethnic, and regional diversity of Ukrainian society. In other words, there is a divide between communities that rely more on "ethnic" and those that rely more on "civic" elements of national identity. Moreover, communities that were established more recently, or "new" ones, are more prone to be "civic." Finally, diasporic communities, like Ukraine itself, demonstrate a lot of ambiguity and overlaps between "civic" and "ethnic" national discourses and symbolism. Before turning to the questions of Ukrainian "ethnic" and "civic" national identifications and their relevance to diasporas, it is necessary to clarify the main concepts of this study.

\section{DIASPORIC IDENTITIES, LANGUAGES, AND SOCIAL MEDIA}

The importance of relationships with the country of origin as a symbolic foundation of a diasporic community is highlighted by Morawska, who defines diasporas as

ethno-national groups whose members reside out of their home country (moved from there either forcibly or voluntarily) and who retain a sense of membership in their group of origin and collective representation [emphasis added-IK] and concern for the well-being of their homeland which plays a significant role in their lives in both symbolic and normative sense. (1030)

This definition not only rules out migrant populations that are not concerned with their country of origin, it also stresses the importance of the collective representation of the homeland and ethnonational foundations of diaspora groups. Also, diasporic language(s) is normally recognized as a crucial element of diasporic identity (Androutsopoulos). Here, particular languages that are used for the representation of national belonging and language choices in social interactions bring additional insights into the relationships between diasporic languages and identities. Since Ukraine is represented by different linguistic and ethnic groups united by one state, these choices can be seen as important identity markers that demarkate symbolic boundaries 
of a community and reflect a particular mode of national "imagination" (Anderson 6).

Another significant factor that affects various diasporas is information and communication technology (ICT). The centrality of the role of contemporary ICT for diasporic "imagined communities" is underlined by Arjun Appadurai who argues that these new technological means facilitated the creation of "diasporic public spheres" that enable diasporic communities to "imagine" themselves online. Thus, this "imagination" constitutes a new trend in social life through which collective patterns of diversity and communal life emerge. In order to consider these technological advances, this study utilizes the concept of "digital diaspora" by Michel Laguerre who defines it as

an immigrant group or descendant of an immigrant population that uses ICT connectivity to participate in virtual networks of contacts for a variety of political, economic, social, religious, and communicational purposes that, for the most part, may concern either the homeland, the host country, or both, including its own trajectory abroad. (qtd. in Alonso and Oiarzabal 50)

In order to investigate Ukrainian digital diasporas, this study focuses on the analysis of the representation of Ukraine within online public spaces. To answer the main research question of this study, I analyze how various diasporic communities "imagine" and represent Ukraine online and how national identities are articulated by diaspora activists. Brubaker and Cooper point out that while "identities" are categories of analysis (which is how they are used in this study), national identities come as the showcases or representations of certain symbols and discourses (4-5). For a more nuanced understanding of diasporic national belonging and the role of languages therein, it is necessary to highlight "civic" and "ethnic" aspects of Ukrainian nation-building, as well as their relevance to a diasporic setting.

\section{“Civic” AND “Ethnic” NATiOnalism And DiasPoRic IDEnTities}

After the collapse of the Soviet Union, Ukraine's national discourses produced diverse, often competing, national myths and historical narratives. These processes are well documented and consider "civic" and "ethnic" identifications (Shulman). These identifications should not be collapsed together since both are national but emphasize different aspects of national identity, and thus refer to specific national "imagination." "Civic" nationalism refers to the sense of belonging to a political community and "ethnic" - to the sense of belonging to a cultural and linguistic one (Hobsbawm, Nations 6). Taras Kuzio points out that there are limitations to the definitions of 
nationalism as being either "civic" or "ethnic," because nearly all nations possess an "ethno-cultural core"-well-defined preferences on languages, cultures, and historical myths (158). This paper acknowledges these limitations but adopts a distinction between "civic" and "ethnic" ideas of the Ukrainian nation for analytical purposes. But how do we define "civic" diasporic nationalism? While "ethnic" foundations of diasporic nationalism are well researched, its "civic" forms require additional clarification. Naujoks defines diasporic civic identification as "being a part of the state of origin with rights and responsibilities towards government/political/state institutions" (5). Similarly, Nina Glick Schiller and Georges Eugene Fouron introduce the concept of "trans-citizen" in order to reflect situations where people exercise rights and responsibilities with reference to more than one government (25-26). While the ways rights and responsibilities are exercised and protected by diasporas is an important aspect of diasporic "civic" nationalism, its analysis goes beyond the scope of this study. Instead, this paper focuses on the manner in which Ukrainian diasporic communities "imagine" Ukraine: whether they focus more on "ethnic" elements or "civic" ones in their representations of the homeland, and traces the changes in these processes after the Euromaidan. To better understand these changes, it is necessary to look at the nationalism of Ukrainian diasporas in a broader perspective.

THE MAKING OF UKRAINIAN DIASPORAS BEFORE THE EUROMAIDAN: NATIONALISM AND LANGUAGES

Diasporas are often described as "nationalist," with the adjective implying negative connotations. For instance, Koinova refers to nationalist behaviours of diasporas as aiming "to achieve linguistic, cultural, political, and territorial goals through hate speech, negation of the rights of others, and other extreme ideas and methods" (42). In her study of post-Communist diasporas, she claims that Ukrainian ones were more prone to democratization initiatives mainly because there was no armed conflict in their country of origin. At the same time, many diaspora groups, according to her study, quite often demonstrated nationalist behaviours. Koinova's study suggests that the conflict in the home country makes diasporas more radical and less democratic. In the present paper, this argument is tested with empirical evidence.

Per Anders Rudling, in his study of Ukrainian diaspora monuments and memory politics in Canada, claims that Ukrainian nationalism of diasporic communities is based on the glorification of war-time leaders of the Organization of Ukrainian Nationalists (OUN) like Stepan Bandera and Roman Shukhevych. According to Rudling, this reflects a promotion of 
radical "ethnic" nationalism that is "often at odds with the liberal democratic values" (757). This claim implies an ideological monism of diasporic communities. Other studies, however, contradict this claim and point out that in some countries promoters of this conservative "ethnic" identity have established a hegemonic discourse, like in the case of the Association of Ukrainians in Great Britain or AUGB (Smith and Jackson). In many other cases, including Canada, diasporic communities always were and remain highly heterogenous in cultural and ideological terms (Isajiw; Satzewich). For instance, Serge Cipko, in his research on Ukrainian diasporas in Argentina, suggests that diasporic communities articulated a variety of "ethnic" and "civic" identities. Nonetheless, defence and representation of a war-time nationalist struggle by diasporas can be seen as "ethnic" identification and is considered as such in this paper.

Previous studies on Ukrainian diasporas suggest their strong focus on preserving Ukrainian language, ethnic culture, and particularly the strong ties with western Ukrainian regions (Isajiw; Satzewich; Cipko; Smith and Jackson). Naujoks stresses that diasporic-regional identifications are important and should be considered in national and civic terms (6). Taking this thesis further, I argue that concern for and identification with regions that were not historically relevant to a given diasporic community point out more "civic" identifications, as they are based on state borders. This argument corresponds with theorizations on diaspora by Anthony Smith, who stresses the importance of symbolic territorialization (attachments of a community to "its" territory, which is seen as an historic homeland) (5).

In this study, diasporic identity is seen as constructed around a complex combination of "ethnic" and "civic" elements. Therefore, for a better understanding of representations and articulations of diasporic identities, it is important to highlight some distinctions between these "ethnic" and "civic" elements that are related to the case of Ukraine. Ukraine here should be understood as an "imagined" entity that is constantly reconstructed and represented by various sets of ideas, symbols, and narratives. Employing the ideas of the studies above, I argue that a focus on the symbolism of the World War II nationalist struggle, on Ukrainian monolingualism, and on ethnic arts and culture, alongside a focus on particular regions of Ukraine, may serve as an indicator of "ethnic" national "imagination," whereas efforts to move away from conservative nationalist narrative, inclusivity toward Ukrainian people of different linguistic and ethnic backgrounds (in particular, the Russian-speaking background), and recognition of regional diversity in Ukraine indicates more "civic" national belonging. While some approaches conceptualize national identity in "either-or" terms, I stress that diasporic identities are essentially hybrid and may include various combinations of these elements. In order to test these theoretical claims with empirical data, this study employed a combination of qualitative research techniques. 


\section{RESEARCH DATA AND METHOdOLOGY}

Following the suggestion by Shani Orgad that a combination of on- and offline data increases research validity and reliability, this study employed several qualitative techniques that are applied "on both sides of the screen" (35). The online part of my investigation relied on qualitative content analysis (following Herring 234-35) with a focus on the main themes relevant to the research: representation of memory of the WW II national struggle, languages and ethnic cultures, and Ukrainian regional identities. This technique allowed me to outline the most common themes, symbols, and narratives that were used by specific communities in their representation of the homeland. Specific attention was paid to the community description, its stated goals and objectives, available language options, and topics of posts by administrators and commentators. This technique was applied to a theoretical sample of 16 digital diasporas based in Canada, the United Kingdom, Germany, Hungary, and the Czech Republic (see Table 1). These communities either had their own websites or Facebook groups, or both. Several of these diasporic communities were formal diaspora organizations, such as the Ukrainian Canadian Congress, while others were grassroots initiatives, like the "Ukrainian Cinema Club in Berlin" or "Ukrainians in Edmonton."

In addition to qualitative content analysis, link analysis was applied to see how diasporic communities are connected online and whether they share content of and membership in social media groups. Here, analysis included sites that have reference to the one being studied (in-links) and sites that are linked by the site under examination (out-links) (Hine 94-95). In the case of social media groups, out-links came under the section "Pages Liked by this Page." This examination was crucial for understanding and evaluating the relationships between diasporic sites and social media groups as nodes of a social network. Also, diaspora activists were asked about relationships between communities identified by link analysis.

The offline element of this study included 24 semi-structured interviews with diaspora activists from twelve communities identified during the online investigation. The professional backgrounds of activists ranged from skilled manual to professional work; journalists, writers, poets, and academics were included in the study. The sample of diaspora activists is fairly balanced in terms of gender (14 men and 10 women). The interview guide included the following themes: memory and national identity, languages in Ukraine and in the diasporic setting, an ongoing conflict between Russia and Ukraine. All data was collected over the period from June 2015 to November 2017. Onand offline data was brought together and analyzed using a framework technique that allowed the separation of particular themes relevant to the research questions and the identification of variations within these themes 
(Ritchie and Lewis). Data irrelevant to the main research questions was removed, but while the main thematic blocks (memory, language, ethnicity, and regionalism) were predefined before data collection, their content, the most popular themes and symbols, and their internal variations were identified only at the stage of data analysis.

The combination of rich and diverse data from different sources allowed for data triangulation, and additional crosschecks presented a broad and detailed picture of online representations of national belonging within Ukrainian diasporic communities after the Euromaidan revolution.

\section{FINDINGS AND DISCUSSION}

Before turning to the discussion of findings related to the three themes of this study-memory and national identity, ethnicity and languages, and regionalism - it is necessary to explain how these communities are linked to each other. Link analysis revealed that Ukrainian digital diasporas constitute distinct clusters where every community can be seen as a node that is embedded in a multi-layered social network. The studied communities can be separated into two distinct categories: "old" and "new" diasporas. Here, "old" refers to predominantly formal diasporic organizations that have existed for a long time and are united by the Ukrainian World Congress (UWC). The UWC is an umbrella organization that describes itself as the "international coordinating body for Ukrainian communities in the diaspora representing the interests of over 20 million Ukrainians" ("About the UWC"). The UWC and its affiliate communities declare similar goals that broadly refer to the protection of Ukraine's independence and sovereignty; its religious, linguistic, and cultural heritage; the rights of Ukrainian communities; and Ukraine's democratic development.

Many of the "new" communities emerged after 2014 and most of them are grassroots initiatives that do not have a formal affiliation with the UWC. As noted by activists from these communities, social media provides a perfect platform to organize various events and activities without creating a formal organization or a dedicated website. The majority of these "new" communities in the sample are connected by the "Global Ukraine" initiative. ${ }^{2}$ This initiative emerged in 2015 to promote Ukraine's national interests with the "development of a strategy of public cultural and business diplomacy using a communication platform, which involves the most active Ukrainian expats and leaders of post-Maidan movements" ("About Us"). Also, the platform encourages citizen journalism in order to resist Russian

${ }^{2}$ https://global-ukraine.com. Accessed 07 Nov. 2017. 
propaganda. This platform predominantly unites people who represent the fourth wave of migration.

While link analysis shows that many communities of these two groups overlap online, the data coming from the interviews points out varying distances between "old" and "new" communities in different countries. In Canada and Germany both groups are not only connected online, they actively interact offline. In contrast, in the UK, "old" and "new" communities have very limited co-operation. The Czech Republic and Hungary constitute an interesting case, as in both countries Ukrainian diasporas were established quite recently, but they are deeply integrated into the UWC. Having pointed this out, we can now look closer at symbols and memory narratives used by diasporas to represent their national belonging and discuss how these have changed in recent years.

\section{MEMORY AND NATIONAL IDENTITY}

What derives from the analysis of online representations within both groups is that Ukrainian digital diasporas actively use Ukrainian state symbols like the flag and coat of arms in online articulations of national belonging. Moreover, across all communities there is visible support of Ukrainian state institutions. This is different from pre-Euromaidan times when the Ianukovych regime and pro-government coalition were adopting controversial laws like the one on regional languages in 2012 that gave the Russian language official status. This law faced a very strong resistance from the majority of communities. The UWC has published an official statement condemning the adoption of this law. Also, the neo-Soviet memory politics of the Ianukovych government was widely condemned, especially by the "old" communities. This critical approach toward Ukrainian state institutions peaked during the Euromaidan with Ukrainian diasporas strongly supporting the protesters and condemning the Ianukovych government. This antagonistic approach changed after the pro-European government came to power in February 2014. The subsequent Russian aggression evidently made clear that the Ukrainian state is under threat, highly mobilizing diasporas for its preservation. A significant effort was made to legitimize state institutions like parliament and the presidency with the UWC sending significantly more observers to the Ukrainian elections after the Euromaidan. The analysis of online discourses also shows continuing support of the Ukrainian state, with only rare criticism of the slow implementation of reforms and the limited progress in fighting corruption in Ukraine. These developments can be seen as the increase of "civic" identifications after the Euromaidan. More differences can be traced, 
however, in relation to memory and historical narratives that are articulated both on- and offline.

The efforts to advocate a conservative historical narrative are more common in the "old" communities whereas "new" ones generally do not engage in historical representations. This study reveals systematic attempts to mobilize community members by using symbols of the conservative "national imagination," discursively connecting them to the ongoing conflict with Russia. This is another illustration of how the Russian aggression against Ukraine made "ethnic" symbols from the past relevant and mobilized them in the contemporary situation, as demonstrated by Kulyk's study on the symbolism of the Euromaidan ("Ukrainian Nationalism"). These symbols, however, are not universally internalized, indicating some degree of fragmentation in the diasporic national "imagination." There is a visible divide between "old" and "new" diaspora communities. "Old" communities tend to be more "ethnic" in terms of the representation of their national belonging, which is evident from the online showcase of Ukrainian identity and comments by diaspora activists. "Old" communities predominantly rely on the symbolism of the World War II struggle for independence. Here, numerous online publications of these communities are "re-enforced" by portraits of Bandera ${ }^{3}$ or the black-and-red flag of the Ukrainian Insurgent Army. While some official organizations affiliated with the UWC do not have a lot of visual or textual materials related to this conservative national narrative, their official declarations point to the support and internalization of this narrative, e.g., their official condemnation of the recent amendments to the Act on the Institute of National Remembrance in Poland that effectively criminalized recognition and glorification of the Ukrainian national resistance during World War II ("Ukrainian World Congress President"). Similar responses were observed before the Euromaidan when the Ukrainian conservative historical narrative was challenged (Kozachenko, "Eastern Slavic Diasporas," 162). The processes of post-2014 "re-invention" of national belonging by "old" communities are well reflected by online visual materials. For instance, in the online announcement of the "Day of Heroes"4 celebration by the AUGB in 2014-15, portraits of heroes from the past (Bandera and Shukhevych) were combined with contemporary heroes - an iconic picture of the Heavenly Hundred. ${ }^{5}$ Another example is the poppy flower that symbolizes the day of commemoration and reconciliation and also refers to the end of World War II. The design of this

3 Bandera was one of the leaders of the radical faction of the Organization of Ukrainian Nationalists (OUN) during and after World War II.

4 This holiday is celebrated on 23 May and it honors the struggle of the OUN and Ukrainian Insurgent Army for Ukraine's independence during the WW II.

598 protesters that were killed during the Euromaidan revolution. 
symbol was developed by a Ukrainian artist in 2014 and since has become an official symbol of the commemoration of World War II victims. This symbol was widely used by "old" diasporic communities, illustrating how old symbolism merges with the new. The Ukrainian national struggle during World War II is a divisive topic for "new" Ukrainian diasporic communities. While some activists from "new" diasporas do not consider the war-time Ukrainian nationalist organizations to be controversial, the majority see them as quite problematic. The supporters of such representation of national identity rather see this controversy as caused by a lack of information about the Ukrainian national struggle. In this view, Ukrainians and host societies who are critical of the conservative national narrative, just have to be enlightened for the problem to be solved. This reasoning is demonstrated by one activist from the "new" community in the Czech Republic:

[Translated from Ukrainian] ${ }^{6}$ We have books about Bandera. They [Czech people-IK] were very afraid of red-and-black flag before, because they were thinking that it is related to fascism and for them it was unacceptable that people come to the Maidan with such flags. Only blue-and-yellow flags were accepted. But when we were explaining to them who Bandera was and what kind of movement it was, they changed their views. There are books and they are all translated. But they do not sell them freely here. There is one man who studied Bandera and he holds a lot of meetings and appears a lot on TV. He is a historian, he is Czech, and he speaks perfect Ukrainian. And he tells all the truth on TV. Now Czech people know more about Iarosh ${ }^{7}$ and Bandera. (Activist, 29 Sept. 2015)

This quote also shows how World War II nationalistic leaders are discursively equated to one of the leaders of a contemporary right-wing organization in Ukraine, Dmytro Iarosh of Pravyi Sektor. At the same time, those activists have a critical attitude toward conservative representations, explaining that they do not provide an inclusive framework for non-ethnic Ukrainians, and that glorification of war-time leaders causes negative reactions from Poland, Germany, and Israel.

Overall, these findings suggest that diasporic "civic" identifications became stronger after the Euromaidan with the universal support of the Ukrainian state by the studied communities. Memory politics, however, remains a divisive issue, making national "imagination," especially within "old" communities, more "ethnic" and thus less inclusive. The internalization of the conservative narrative by some of the "new" communities illustrates how the Russian aggression against Ukraine made the symbols from the past

\footnotetext{
${ }^{6}$ All translations are my own.

7 Dmytro Iarosh is the leader of the contemporary right-wing organization "Tryzub" in Ukraine.
} 
relevant and mobilizing in the contemporary situation. Such memory politics and symbolism, although controversial and possessing lesser inclusive potential, can hardly be considered "extreme ideas," as described by Koinova (42), as there is no data to suggest that both groups of diasporas support radical actions or undemocratic practices, especially considering the European aspirations of Ukraine. The issues of languages and multiethnicity, however, remain challenging for the diasporas.

\section{LANGUAGES AND ETHNIC IDENTITIES}

The Ukrainian language serves as one of the central identity markers for all Ukrainian diasporic communities. However, its use is more ambiguous outside official public spaces, and the presence of the Russian language and the idea of multi-ethnic Ukrainian identity is problematic mainly for the "old" diasporic communities. It is evident that many "new" communities try to develop a more "civic" framework for social interactions online. The group "Ukrainians in Canada" sets a good example with the following description (in Ukrainian):

[Translated from Ukrainian] This group is for those who have come from Ukraine and for those who identify themselves with Ukraine. It does not matter what language you speak and what church you go to or not go to ... . Languages of communication in this group: Ukrainian, Russian, English, and French. ("Ukraintsi v Kanadi")

Such a description refers to "civic" understanding of Ukraine's identity and encompasses the official languages of the host country. Another community, "Ukrainians in Berlin," relies on a similar "civic" frame, as its description reads (in Ukrainian): "Everyone who does not share xenophobic, racist or sexist views is welcomed here. This groups serves as the meeting place for Ukrainian- and Russian-speaking Berliners. In this group we speak Ukrainian and Russian. We also encourage the speaking of German here" ("Ukrainians in Berlin").

Qualitative content analysis of online diasporic spaces reveals differences between entries produced by administrators of social media groups and regular participants. In these entries, administrators tend to use Ukrainian and, less often, the language of the host country. Thus, Ukrainian serves as the only "official" language of online communities. In contrast, online discussions within these communities are predominantly bilingual: in Ukrainian and Russian. This observation is more relevant to social media groups that do not represent "old" diasporic organizations where comments in Russian are nearly absent, but comments in the host country language are 
very common. On 27 occasions during the study period, stigmatization of the Russian language was documented. On those occasions, those writing in Russian were accused of being "not true Ukrainians" and the language itself was labelled with different names, for example, "the dog's language." Such discussions were clearly an exception in the generally inclusive multilingual environment of diasporic communities online.

However, it seems to be a quite complicated task to overcome the "ethnic" vision of Ukrainian identity for "old" organizations linked to the UWC. For them, the Russian aggression against Ukraine has reinforced previously existing narratives of Russia (and the Russian language as its symbolic attribute) as being ontologically hostile to Ukraine and Ukrainians. Such struggle is very visible online. The aggression has revived the idiomatic expression "occupier's language" in describing Russian, which has now taken on a new and more literal meaning with Crimea and parts of Donbas occupied by the Russian Federation. At the same time, there are significant changes taking place in "old" communities that are noted by a number of activists, with Russian becoming more acceptable when used by someone who identifies with Ukraine. A radio deejay from Canada recalls the following situation reflecting these changes:

Well, there was an interview with one volunteer on "Radio Svoboda." It was a very important interview and I decided that I have to have it broadcasted on our radio channel. And this interview was in Russian. And, you know, there were no complaints after this broadcast. Not a single one. If I had done this before the Euromaidan, I would have been crucified for doing this (laughs). (29 Nov. 2015)

Evidently, various linguistic identities are accommodated by a sense of belonging to the Ukrainian state and joint efforts to protect this state from external aggression. Therefore, the Ukrainian diasporic identity includes several layers, thus creating a combination that can be visualized as concentric circles or the "Matryoshka doll" where one "bigger" identity has many "smaller" ones inside (Herrmann and Brewer). Here Ukrainian is a "bigger" identity that includes "smaller" ones of Russian and the language of the host country.

The inclusion of non-ethnic Ukrainians into diasporic communities is a challenging issue that demonstrates quite positive dynamics. Non-ethnic Ukrainian activists from Germany, Canada, the Czech Republic, and the UK underline that they have rediscovered their "Ukrainianness" and the sense of belonging to Ukraine after the Euromaidan. In these conversations, the fact that it was easier to connect with the Euromaidan's "civic" identity was strongly emphasized. The case of Germany is a salient illustration of how "new" communities construct more inclusive "civic" frames to integrate Jewish people of Ukrainian origin. One of the activists, a musician who helps 
internally displaced persons (IDPs) in Ukraine and also supports the Ukrainian Army, reflects upon her experiences:

[Translated from Russian] And I played for them (volunteer battalions) and I openly told them that one composition is a Jewish prayer. I told them that I am a Ukrainian of Jewish religion and I cannot pray the Christian way, but I will pray for you the way I can. And this was accepted... It was accepted very positively. Of course, I could see that some people struggle with this and had some shock. If someone would ask me I would say, "I neither support the ideology of OUN nor the Right Sector, but if there is an opportunity for contact I will use it." If we want to be a democratic country we cannot get rid of these people. We have to educate these people. . . I I believe in free, democratic and independent Ukraine. (Activist, Germany, 12 Nov. 2015).

This quote demonstrates not only support of the home country, but also some tensions with conservative ideology. Other activists from Germany stressed that while they actively support Ukraine, its representation in traditional "ethnic" terms is problematic for the host society and in community-making processes.

A very important change in terms of the representation of Ukrainian national identity by both "old" and "new" communities is the wide recognition and acknowledgement of Crimea and Crimean Tatars as an integral part of Ukraine. While materials on Crimean Tatars were virtually absent within diasporic online spaces before 2014, after the Crimean Peninsula was annexed by Russia, various visual and textual materials became very common. For instance, the Crimean Tatar flag and quotes from interviews with Crimean Tatar leaders were posted dozens of times in diasporic groups online. The victory of Crimean Tatar singer Jamala at the Eurovision song contest in 2016 also significantly contributed to such inclusive representations. Notably, during a conference at the University of Alberta in 2017, the President of the Association of Crimean Tatars in Canada Rustem Irsay said that the Association has full support and co-operates closely with a wider Ukrainian diaspora, but such co-operation began only in 2014.

Overall, the problems in accommodating linguistic and ethnic diversity, especially by "old" diasporas, can be explained using the arguments of Kulyk, who points out that the absence of the Ukrainian state (and, by association, the fact that Ukrainian diasporas prior to 1991 were stateless) resulted in nearly exclusive "ethnic" understanding of the Ukrainian identity ("Language and Identity," 590). In other words, during Soviet times, Ukrainian identity was largely understood in ethnocultural terms. This was even more the case in diasporic social settings where Ukrainian language and traditional ethnic arts constituted the core of the "resistance identity" 
(Castells 8). Here "resistance" refers on the one hand to the Ukrainian national struggle during the twentieth century, and on the other hand to resistance to assimilation processes in the host countries. Therefore, for Ukraine itself and for Ukrainian diasporas worldwide, the processes and challenges of "re-imagining" the national identity refer first and foremost to the development of more inclusive "civic" frames. The emergence of the latter is mainly evident in "new" communities, but "old" ones also demonstrate positive dynamics. Another challenge for "old" communities is the inclusion of eastern and southern Ukrainian regions in their "imagined community."

\section{REGIONAL DIVERSITY}

The data points out that the events of the Euromaidan, and especially the Russian aggression, have significantly expanded territorial identifications of Ukrainian digital diasporas. The lack of support for separatism and the failure of the "Russian Spring" uprising in the majority of southern and eastern regions of Ukraine demonstrated that the common diasporic perception that these regions are essentially "pro-Russian" or "separatist" is generally misleading. Also, these events undermined a common portrayal of a Ukrainian patriot as being necessarily a Ukrainian-speaking person from western Ukraine, as many soldiers fighting for Ukraine are from the eastern part of the country. Here, extensive media coverage of the events in Donbas and eastern regions of Ukraine has contributed to such changes in perceptions within diasporic communities. That these developments have resulted in a better emotional connection to the eastern regions as the "homeland" or "own" land (Smith) is noted by an activist from an "old" community in the UK:

Well, here in the diaspora, we always had a suspicion that eastern and southern Ukraine is tempted to join Russia. You know, all these votes for Ianukovych and the Party of Regions. Especially, for the older generation [in the diaspora-IK] it was hard to see how someone who speaks Russian and lives in Kharkiv, for example, can feel Ukrainian, not to say to fight for Ukraine. So, it was a great surprise that Ukraine stayed united during the so called "Russian Spring" and that Russia has managed to occupy comparatively small territory. ... I guess, people in the diaspora have a better understanding of eastern regions of Ukraine and have placed these regions on their mental map now. (Activist, 13 June 2015)

A traceable emergence of a more inclusive frame toward Crimea, and the evident integration of eastern and southern Ukraine into a national "imagined community," points out a very important tendency: the events 
during and after the Euromaidan have significantly expanded what was formerly perceived as the "authentic homeland." Western Ukrainian territories that were historically relevant to "old" diasporas in terms of attachment, as described by Isajiw and Satzewich, are now expanded by other regions of Ukraine. For "new" communities this task was much easier, as their demographic compositions reflected regional diversity much better than that of "old" ones. Nonetheless, the wide range of humanitarian activities directed to eastern Ukraine by organizations like the UWC demonstrates a growing awareness of the regional diversity of Ukraine. For instance, during a meeting in July 2015 in the town of Sloviansk in eastern Ukraine that was liberated from pro-Russian separatists, the Director of Representative Office of the UWC stressed that Ukrainians should overcome language, religious, and regional divides using the experience of the Euromaidan ("MTsPD proviv). Although this is not the official position of the UWC, it shows a recognition of regional and ethnolinguistic diversity in Ukraine and a realization of the importance to develop an inclusive "civic" framework. Writing about eastern regions of Ukraine, Tatiana Zhurzhenko stresses that the Russian aggression "catalyzed the creation of a political nation. Ukrainian identity which for so long was associated with ethnicity, language and historical memory, suddenly has become territorial and political and thus inclusive." The results of this study suggest that there is a wider understanding of this within diasporic populations.

This study also takes into account that the processes of territorialization (Smith) within diasporic communities are dynamic, so the noticeable rise in the "civic" diaspora nationalism may be significantly affected, positively or negatively, by social and political developments in Ukraine.

While acknowledging the limitations of "civic" and "ethnic" nationalism dichotomy, this study, highlights how separate elements of these identity complexes are articulated within digital diasporas. The findings above suggest that the Euromaidan and the Russian aggression against Ukraine provided diasporas with a new set of shared myths and symbols where, for instance, Russian-speaking Ukrainians who fight for their homeland are not perceived as Others within "old" communities.

This study demonstrates that these dramatic events definitely provided "old" diasporic communities with new insights into memory politics, and regional, ethnic, and linguistic diversity in Ukraine. For the "old" communities, the conservative national narrative and the Ukrainian language are the "icons of nationalism" that refer to "ethnic" national belonging (Castells, 65). At the same time there is an evident effort, especially by the "new" diasporic communities, to expand social, cultural, and national boundaries with the help of "civic" national identifications. The latter should be treated as a developing part of the diasporic sense of belonging that resonates with the national development of Ukraine. Overall, 
this study demonstrates that despite the ongoing conflict with Russia, there is significant progress in accommodating ethnocultural diversity of Ukraine in the diasporic contexts using "civic" identifications that are distanced from memory politics, and embrace ethnic and linguistic diversity, as well as the regional pluralism of contemporary Ukraine.

\section{CONCLUSIONS}

This paper sought to analyze the dynamic nature of "civic" and "ethnic" national identifications that are lived, performed, and "represented" by Ukrainian digital diasporas in Canada, the UK, the Czech Republic, Germany, and Hungary. These diasporas are multi-layered and diverse social networks that span both sides of the screen and across national borders, uniting local and global, past and present. Diasporic communities are shaped by historical narratives of the distant past and are also affected by contemporary events. Contemporary social media help them to develop "the distinct online networks that diasporic people use to re-create identities, spread their culture, influence homeland and host land policy, or create debate about common-interest issues by means of electronic devices" (Alonso and Oiarzabal 11). Diasporic communities demonstrate the processes of "reimagining" of Ukraine after the Euromaidan revolution within online and offline social spaces. These processes do not offer the satisfaction of a clearcut "ethnic" or "civic" identity-as analyzed in relation to memory, languages, ethnicities, and regional diversity. As the conceptualization of "civic" identifications in this study has not focused on the ways Ukrainian "trans-citizens" protect and exercise their rights and responsibilities (as observed by Schiller and Fouron 25-26), this can be a direction for future research. This paper focused on the work of representation (Bourdieu 727) by diasporic groups, but future research may address the biographical level and the self-understanding within Ukrainian diasporas. This level is crucial in migration and diaspora studies since the classic studies of Thomas and Znaniecki. Also, a quantitative or big data analysis of Ukrainian digital diasporas may bring additional insights into post-Euromaidan developments.

Diasporic communities may be seen as "extensions" of the nation, and this study demonstrates that events in Ukraine have a profound impact on the ways diasporas function and represent their national belonging. Various communities articulate a particular "sense of nation" where linguistic identity plays a crucial role in shaping the communities included in this study. This study illustrates that, while Ukrainian functions as the language of formal communication, diasporic communities provide an inclusive framework for diasporic subjects who speak Russian and for those who are 
non-ethnic Ukrainians but support and identify with Ukraine. Thus, like their homeland, Ukrainian diasporas undergo a complicated transition from a narrow understanding of Ukrainian identity as "ethnic" to a more inclusive "civic" one. This process is in line with Smith's suggestion that: "The nationalism extends the scope of ethnic community from purely cultural and social to economic and political spheres" (19-20). It is hard to predict how sustainable and successful this process will be in the case of Ukraine and its diasporas, as external aggression threatens to make radical ethnonational narratives with simple answers to complicated questions more tempting.

Works Cited

"About the UWC." Ukrainian World Congress, http://www.ukrainianworldcongress.org/index.php/id/231/lang/en. Accessed 15 Jan. 2018.

"About Us." Global Ukraine, https://global-ukraine.com/en/viziya-misiya-tsinnosti/. Accessed 07 Nov. 2017.

Alonso, Andoni, and Pedro Oiarzabal. Diasporas in the New Media Age: Identity, Politics, and Community. U of Nevada P, 2010.

Anderson, Benedict. Imagined Communities: Reflections on the Origin and Spread of Nationalism. Verso Books, 2006.

Androutsopoulos, Jannis. "Multilingualism, Diaspora, and the Internet: Codes and Identities on German-Based Diaspora Websites." Journal of Sociolinguistics, vol. 10, no. 4, 2006, pp. 520-47. DOI: 10.1111/j.1467-9841.2006.00291.x

Appadurai, Arjun. "Grassroots Globalization and the Research Imagination." Public Culture, vol. 12, no. 1, 2000, pp. 1-20. DOI: 10.1111/1468-2451.00191

Bourdieu, Pierre. "The Social Space and the Genesis of Groups." Theory and Society, vol. 14, no. 6, 1985, pp. 723-44.

Brubaker, Rogers, and Frederick Cooper. "Beyond 'Identity.'” Theory and Society, vol. 29, no. 1, 2000, pp. 1-47. DOI: 10.1023/A:1007068714468

Castells, Manuel. The Power of Identity. Wiley-Blackwell, 2004.

Cipko, Serge. Ukrainians in Argentina, 1897-1950: The Making of a Community. Canadian Institute of Ukrainian Studies P, 2011.

Herring, Susan. "Web Content Analysis: Expanding the Paradigm." The International Handbook of Internet Research, Springer, 2010, pp. 233-49.

Herrmann, Richard, and Marilynn Brewer. "Identities and Institutions: Becoming European in the EU." Transnational Identities: Becoming European in the EU, Rowman \& Littlefield Publishers, 2004, pp. 1-22.

Hine, Christine. Virtual Methods: Issues in Social Research on the Internet. Berg Publishers, 2005.

Hobsbawm, Eric. Nations and Nationalism since 1780: Myth, Programme, Reality. Canto ed., Cambridge UP, 1990.

Irsay, Rustem. "The Life of Crimean Tatars after the Russian Annexation of Crimea." Film screening of A Struggle for Home: The Crimean Tatars, 2 Feb. 2017, University of Alberta. 
Isajiw, Wsevolod. "The Ukrainian Diaspora." The Call of the Homeland: Diaspora Nationalisms, Past and Present, edited and compiled by Allon Gal, Athena Leoussi and Anthony Smith, Brill, 2010, pp. 289-345.

Katchanovski, Ivan. "The 'Euromaidan,' Democracy, and Political Values in Ukraine.” Bridging Divides: Rethinking Ideology in the Age of Global Discontent, edited by Barrie Axford et al., Routledge, 2018.

Koinova, Maria. "Diasporas and Democratization in the Post-Communist World." Communist and Post-Communist Studies, vol. 42, no. 1, 2009, pp. 41-64. DOI: 10.1016/j.postcomstud.2009.02.001

Kozachenko, Ivan. "Eastern Slavic Diasporas in the UK: The Making of Communities." Dissertation, University of Aberdeen, 2013. http://ethos.bl.uk/OrderDetails.do?uin=uk.bl.ethos.575392. Accessed 20 Aug. 2018.

Kulyk, Volodymyr. "Identity in Transformation: Russian-Speakers in Post-Soviet Ukraine." Europe-Asia Studies, 2017, pp. 1-23. DOI: 10.1080/09668136.2017.1379054

---. "Language and Identity in Ukraine after Euromaidan." Thesis Eleven, vol. 136, no. 1, 2016, pp. 90-106. DOI: 10.1177/0725513616668621

---. "Ukrainian Nationalism since the Outbreak of Euromaidan." Ab Imperio, no. 3, 2014, pp. 94-122. DOI: 10.1353/imp.2014.0064.

Kuzio, Taras. "Competing Nationalisms, Euromaidan, and the Russian-Ukrainian Conflict." Studies in Ethnicity and Nationalism, vol. 15, no. 1, 2015, pp. 157-69. DOI: $10.1111 /$ sena.12137.

Marples, David, and Frederick Mills. Ukraine's Euromaidan: Analyses of a Civil Revolution. Columbia UP, 2014.

Morawska, Ewa. "Diaspora 'Diasporas' Representations of Their Homelands: Exploring the Polymorphs." Ethnic and Racial Studies, vol. 34, no. 6, 2011, pp. 1029-48.

"MTsPD proviv dyskusiiu shchodo natsional'noho prymyrennia u Slov"ians'ku." Natsional'nyi dialoh, http://ndialog.org.ua/mtspd-proviv-dyskusiyu-schodonatsionalnogo-prymyrennya--u-slovyansku. Accessed 28 Jul. 2016.

Naujoks, Daniel. "Diasporic Identities-Reflections on Transnational Belonging." Diaspora Studies, vol. 3, no. 1, 2010, pp. 1-21. DOI: 10.1080/09739572.2010.10597338

Orgad, Shani. "How Can Researchers Make Sense of the Issues Involved in Collecting and Interpreting Online and Offline Data?" Internet Inquiry: Conversations about Method, edited by Annette Markham and Nancy Baym, SAGE, 2009, pp. 33-53.

Parham, Angel Adams. "Internet, Place, and Public Sphere in Diaspora Communities." Communities, vol. 14, no. 3, 2005, pp. 349-80. DOI: 10.1353/dsp.0.0020.

Ritchie, Jane, and Jane Lewis. Qualitative Research Practice: A Guide for Social Science Students and Researchers. Sage Publications Ltd., 2003.

Rudling, Per Anders. "Multiculturalism, Memory, and Ritualization: Ukrainian Nationalist Monuments in Edmonton, Alberta." Nationalities Papers, vol. 39, no. 5, 2011, pp. 733-68. DOI: 10.1080/00905992.2011.599375

Satzewich, Vic. The Ukrainian Diaspora. Routledge, 2002.

Schiller, Nina Glick, and Georges Eugene Fouron. Georges Woke Up Laughing: LongDistance Nationalism and the Search for Home. Duke UP, 2001. 
Shulman, Stephen. "Sources of Civic and Ethnic Nationalism in Ukraine." Journal of Communist Studies and Transition Politics, vol. 18, no. 4, 2002, pp. 1-30. DOI: 10.1080/714003618.

Smith, Anthony. The Ethnic Origins of Nations. Wiley-Blackwell, 1986.

Smith, Graham, and Peter Jackson. "Narrating the Nation: The 'Imagined Community' of Ukrainians in Bradford.” Journal of Historical Geography, vol. 25, no. 3, 1999, pp. 367-87. DOI: 10.1006/jhge.1999.0120

Thomas, William, and Znaniecki, Florian. The Polish Peasant in Europe and America: Monograph of an Immigrant Group. Chicago UP, 1918.

"Ukrainian World Congress President Urges Polish President to Reconsider Amendment to Act on the Institute of National Remembrance." Ukrainian World Congress, http://www.ukrainianworldcongress.org/news.php/news/1785. Accessed 18 Feb. 2018.

in Berlin." Facebook, https://www.facebook.com/groups/ukrainiansinberlin/. Accessed on 21 July 2017.

"Ukraintsi V Kanadi-Ukrainians in Canada." Facebook, https://www.facebook.com/groups/canadaua/about/. Accessed 11 Nov. 2017.

Zhurzhenko, Tatiana. "From Borderlands to Bloodlands." Eurozine, https://www.eurozine.com/from-borderlands-to-bloodlands/. Accessed 12 Dec. 2014. 


\section{Appendix 1. Social media groups and websites included in this study}

\begin{tabular}{|c|c|c|}
\hline $\begin{array}{c}\text { Name of Diasporic } \\
\text { Organization/Community }\end{array}$ & Facebook Group Address & Website Address \\
\hline 1. Ukrainian World Congress & $\begin{array}{l}\text { http://www.facebook.com/UWC } \\
\text { ongress/ }\end{array}$ & $\begin{array}{l}\text { http://www.ukrainianworldco } \\
\text { ngress.org/ }\end{array}$ \\
\hline $\begin{array}{l}\text { 2. League of Ukrainian } \\
\text { Canadians }\end{array}$ & $\begin{array}{l}\text { https://www.facebook.com/Leag } \\
\text { ueofUkrainianCanadians }\end{array}$ & http://www.lucorg.com \\
\hline 3. Ukrainian Canadian Congress & $\begin{array}{l}\text { https://www.facebook.com/ukrc } \\
\text { ancongress/ }\end{array}$ & http://www.ucc.ca \\
\hline $\begin{array}{l}\text { 4. Association of Ukrainians in } \\
\text { Great Britain }\end{array}$ & $\begin{array}{l}\text { http://www.facebook.com/AUG } \\
\text { B.SUB/ }\end{array}$ & http://www.augb.co.uk \\
\hline $\begin{array}{l}\text { 5. International Organization of } \\
\text { Ukrainian Communities "Forth } \\
\text { Wave" }\end{array}$ & - & http://www.4thwave.org/ \\
\hline 6. Ukrainians in Edmonton & $\begin{array}{l}\text { http://www.facebook.com/grou } \\
\text { ps/298340710371684/ }\end{array}$ & - \\
\hline $\begin{array}{l}\text { 7. Ukrainian National } \\
\text { Federation in Canada } \\
\text { (Edmonton Branch) }\end{array}$ & $\begin{array}{l}\text { http://www.facebook.com/Ukrai } \\
\text { nian-National-Federation-of- } \\
\text { Canada-Edmonton-branch- } \\
\text { 358133204242169/ }\end{array}$ & http://www.unfedmonton.ca/ \\
\hline 8. Ukrainians in Canada & $\begin{array}{l}\text { http://www.facebook.com/grou } \\
\text { ps/canadaua/about/ }\end{array}$ & - \\
\hline 9. Ukrainians in Berlin & $\begin{array}{l}\text { http://www.facebook.com/grou } \\
\text { ps/ukrainiansinberlin/ }\end{array}$ & - \\
\hline $\begin{array}{l}\text { 10. Ukrainian Cinema Club in } \\
\text { Berlin }\end{array}$ & $\begin{array}{l}\text { http://www.facebook.com/grou } \\
\text { ps/328911452592/about/ }\end{array}$ & - \\
\hline $\begin{array}{l}\text { 11. Central Union of Ukrainians } \\
\text { in Germany }\end{array}$ & - & $\begin{array}{l}\text { http://zentralverband- } \\
\text { ukrainer.de/ }\end{array}$ \\
\hline $\begin{array}{l}\text { 12. Ukrainian Initiative in Czech } \\
\text { Republic }\end{array}$ & - & http://www.ukrajinci.cz \\
\hline $\begin{array}{l}\text { 13. Ukrainians in Czech } \\
\text { Republic }\end{array}$ & $\begin{array}{l}\text { http://www.facebook.com/grou } \\
\text { ps/894596683894634/ }\end{array}$ & - \\
\hline 14. London Euromaidan & $\begin{array}{l}\text { http://www.facebook.com/londo } \\
\text { n.maidan }\end{array}$ & http://saveukraine.co.uk \\
\hline 15. Ukrainians in Hungary & $\begin{array}{l}\text { http://www.facebook.com/grou } \\
\text { ps/ukrainiansinhungary/ }\end{array}$ & - \\
\hline $\begin{array}{l}\text { 16. Ukrainian Cultural } \\
\text { Association in Hungary }\end{array}$ & - & http://www.ukrajinci.hu \\
\hline
\end{tabular}

